\title{
Effect of Obesity on Gestational and Perinatal Outcomes
}

\section{Efeito da obesidade sobre os resultados gestacionais $e$ perinatais}

\author{
Sônia Regina Cabral Madi ${ }^{1}$ \\ Breno Fauth de Araújo ${ }^{1}$ José Mauro Madi ${ }^{1}$ \\ ${ }^{1}$ Gynecology and Obstetrics Department, Hospital Geral, Fundação \\ Universidade de Caxias do Sul, Caxias do Sul, Rio Grande do Sul, \\ RS, Brazil \\ 2 Endocrinology and Nutrition Department, Fundação Universidade \\ de Caxias do Sul, Caxias do Sul, Rio Grande do Sul, RS, Brazil \\ ${ }^{3}$ Neonatology Department, Fundação Universidade de Caxias do Sul, \\ Caxias do Sul, Rio Grande do Sul, RS, Brazil
}

\section{Vandrea Carla de Souza ${ }^{3}$ Renato Luís Rombaldi ${ }^{1}$}

Address for correspondence José Mauro Madi, MD, PhD, Hospital Geral de Caxias do Sul, Av. Prof. Antonio Vignolli, 255-Bairro Petrópolis, 95001-970-Caxias do Sul - RS - Brasil (e-mail: jmmadi@ucs.br).

Rev Bras Ginecol Obstet 2017;39:330-336.

\begin{abstract}
Purpose To assess the impact of pre-pregnancy obesity (body mass index [BMI] $\geq 30 \mathrm{~kg} / \mathrm{m}^{2}$ ) on the gestational and perinatal outcomes.

Methods Retrospective cohort study of 731 pregnant women with a BMI $\geq 30 \mathrm{~kg} / \mathrm{m}^{2}$ at the first prenatal care visit, comparing them with 3,161 women with a BMI between $18.5 \mathrm{~kg} / \mathrm{m}^{2}$ and $24.9 \mathrm{~kg} / \mathrm{m}^{2}$. Maternal and neonatal variables were assessed. Statistical analyses reporting the demographic features of the pregnant women (obese and normal) were performed with descriptive statistics followed by two-sided independent Student's $t$ tests for the continuous variables, and the chi-squared $\left(x^{2}\right)$ test, or Fisher's exact test, for the categorical variables. We performed a multiple linear regression analysis of newborn body weight based on the mother's BMI, adjusted by maternal age, hyperglycemic disorders, hypertensive disorders, and cesarean deliveries to analyze the relationships among these variables. All analyses were performed with the $R$ ( $R$ Foundation for Statistical Computing, Vienna, Austria) for Windows software, version 3.1.0. A value of $p<0.05$ was considered statistically significant.

Results Obesity was associated with older age [OR 9.8 (7.8-12.2); $p<0.01$ ], hyperglycemic disorders [OR 6.5 (4.8-8.9); $p<0.01$ ], hypertensive disorders [OR 7.6 (6.1-9.5); $p<0.01$ ], caesarean deliveries [OR $2.5(2.1-3.0) ; p<0.01$ ], fetal

Keywords

- obesity

- body mass index

- pregnancy outcomes

- neonatal outcomes macrosomia [OR 2.9 (2.3-3.6); $p<0.01$ ] and umbilical cord pH [OR 2.1 (1.4-2.9); $p<0.01)$. Conversely, no association was observed with the duration of labor, bleeding during labor, Apgar scores at 1 and 5 minutes after birth, gestational age, stillbirth and early neonatal mortality, congenital malformations, and maternal and fetal injury.
\end{abstract}

received

May 29, 2016

accepted

March 6, 2017

published online

June 23, 2017
DOI https://doi.org/

10.1055/s-0037-1603826.

ISSN 0100-7203.
Copyright (e 2017 by Thieme Revinter

Publicações Ltda, Rio de Janeiro, Brazil

License terms

c) $(1) \$$ 


\section{Resumo}

\author{
Palavras-chave \\ - obesidade \\ - índice de massa \\ corpórea \\ - desfechos \\ gestacionais \\ - desfechos \\ neonatais
}

Conclusion We observed that pre-pregnancy obesity was associated with maternal age, hyperglycemic disorders, hypertension syndrome, cesarean deliveries, fetal macrosomia, and fetal acidosis.

Objetivo Avaliar o impacto da obesidade pré-gestacional (índice de massa corpórea $[\mathrm{IMC}] \geq 30 \mathrm{~kg} / \mathrm{m}^{2}$ ) sobre os resultados gestacionais e perinatais.

Métodos Estudo transversal retrospectivo, com 731 gestantes que apresentaram IMC $\geq 30 \mathrm{~kg} / \mathrm{m}^{2}$ na primeira consulta de pré-natal, comparando-as a 3.161 gestantes com IMC entre $18,5 \mathrm{~kg} / \mathrm{m}^{2}$ e $24,9 \mathrm{~kg} / \mathrm{m}^{2}$. Foram avaliadas variáveis maternas e neonatais. A análise estatística baseou-se nas características demográficas das gestantes (obesas e com peso normal), e foi realizada com estatísticas descritivas seguidas de testes $t$ de Student independentes bicaudais para variáveis contínuas, e teste de qui-quadrado $\left(\mathrm{X}^{2}\right)$ ou exato de Fisher para as variáveis categóricas. Foi realizada uma regressão linear múltipla do peso do recém-nascido sobre o IMC materno, ajustado por idade materna, síndromes hiperglicêmicas, síndromes hipertensivas hipertensivas e operações cesarianas, a fim de analisar a relação entre essas variáveis. Todas as análises foram realizadas com $o$ uso de $R$ ( $R$ Foundation for Statistical Computing, Viena, Áustria) para Windows, versão 3.1.0. Um valor de $p<0,05$ foi considerado estatisticamente significante.

Resultados A obesidade associou-se à idade materna [OR 9,8 (7,8-12,2); $p<0,01$ ], distúrbios hiperglicêmicos [OR 6.5 (4,8-8,9); $p<0,01$ ], distúrbios hipertensivos (RP: $7,6[6,1-9,5] ; p<0,01)$, maior taxa de operação cesariana [OR $2,5(2,1-3,0)$; $p<0,01$ ], macrossomia fetal [OR 2,9 $(2,3-3,6)$; $p<0,01$ ] e baixo $\mathrm{pH}$ na artéria umbilical [OR 2,1 (1,4-2,9); $p<0,01]$. Não foi observada associação com tempo de trabalho de parto, sangramento durante o trabalho de parto, índice de Apgar no $1^{\circ}$ e $5^{\circ}$ minutos, idade gestacional, natimortalidade e mortalidade neonatal precoce, malformações congênitas e tocotraumatismo materno e fetal.

Conclusões $\mathrm{O}$ estudo mostrou que a obesidade pré-gestacional associou-se com idade materna mais elevada, distúrbios hiperglicêmicos e hipertensivos, taxas mais altas de operação cesariana, macrossomia e acidose fetal.

\section{Introduction}

Obesity is considered one of the largest global health problems of the 21st century. The World Health Organization (WHO) estimated that in 2008, 205 million men and 297 million women over the age of 20 were obese - a total of more than half a billion adults worldwide. ${ }^{1}$ In the WHO Regions of the Americas, $\sim 62 \%$ of the population over the age of 20 were overweight (body mass index [BMI] $\geq 25 \mathrm{~kg} / \mathrm{m}^{2}$ ), and $26 \%$ were obese $\left(\mathrm{BMI} \geq 30 \mathrm{~kg} / \mathrm{m}^{2}\right)$. ${ }^{1,2}$ We should highlight that, in the WHO Region for Europe, the Eastern Mediterranean and the Americas, over $50 \%$ of women were overweight and, of these, about half of overweight women were obese (23\%, $24 \%$ and $29 \%$ respectively). ${ }^{1,2}$ In Brazil, we have little data on the nutritional status of women of reproductive age. Nucci et $\mathrm{al}^{3}$ analyzed the pre-pregnancy nutritional status of women aged 20 to 48 years old between 1991 and 1995 . Their study found pre-obesity (BMI between $25 \mathrm{~kg} / \mathrm{m}^{2}$ and $30 \mathrm{~kg} / \mathrm{m}^{2}$ ) and obesity (BMI $\geq 30 \mathrm{~kg} / \mathrm{m}^{2}$ ) rates of $19.2 \%$ and $5.5 \%$ respectively. ${ }^{3}$ Epidemiological data about disease from the Surveillance of
Risk and Protective Factors for Chronic Diseases by Telephone Survey (VIGITEL, in the Portuguese acronym), which is provided by the Brazilian Institute of Geography and Statistics, showed an increased rate of BMI $>25 \mathrm{~kg} / \mathrm{m}^{2}$ in women aged between $18-24,25-34$, and $35-44$ years old (24.4, 38\%, and $50.9 \%$ respectively). ${ }^{4}$ Such a scenario suggests that obstetricians are dealing more frequently with pregnant women who are overweight and obese and, therefore, have increased risks of poor maternal and child health outcomes. Tennant et $\mathrm{al}^{5}$ found an increased risk of fetal and infant death in a cohort of women who were obese at the beginning of pregnancy compared with women who had the recommended weight, and preeclampsia commonly caused fetal deaths among obese women. Additionally, Aune et al, ${ }^{6}$ in a systematic review and meta-analysis, showed that high a BMI during pregnancy was associated with fetal death, stillbirth, and neonatal, perinatal, and infant death. Nohr et al ${ }^{7}$ reported an association between high pre-pregnancy BMI and excessive maternal weight gain with an increased risk of cesarean delivery (CD), and infants large for their gestational age or with a low Apgar score. ${ }^{7}$ Even 
in developed countries, obese women tend to have a higher likelihood of urinary tract and lower genital tract infections; induced deliveries; $\mathrm{CD}{ }^{8,9}$ severe bleeding in the puerperium period; puerperal infections; ${ }^{8}$ birth defects; fetal death; fetal macrosomia; and maternal death during pregnancy or at childbirth. ${ }^{10-15}$ The present study was performed to evaluate the association of maternal pre-pregnancy obesity with gestational and perinatal outcomes in a population of pregnant women and newborns.

\section{Methods}

This retrospective cohort study was performed by reviewing the medical charts at the Department of Gynecology and Obstetrics from March 1998 to June 2010. According to their BMIs in early pregnancy, the pregnant women were categorized as: underweight (BMI $<18.5 \mathrm{~kg} / \mathrm{m}^{2}$ ); normal weight (BMI between $18.5 \mathrm{~kg} / \mathrm{m}^{2}$ and $24.9 \mathrm{~kg} / \mathrm{m}^{2}$ ); overweight (BMI between $25 \mathrm{~kg} / \mathrm{m}^{2}$ and $29.9 \mathrm{~kg} / \mathrm{m}^{2}$ ); grade 1 obesity (BMI between $30 \mathrm{~kg} / \mathrm{m}^{2}$ and $39.9 \mathrm{~kg} / \mathrm{m}^{2}$ ); and grade 2 and grade 3 obesity (BMI $\geq 40 \mathrm{~kg} / \mathrm{m}^{2}$ ). ${ }^{1}$ All pregnant women with BMI $\geq 30 \mathrm{~kg} / \mathrm{m}^{2}$ and their respective newborns were included in the obese group (OG). And all pregnant women in the normal weight category were included in the normal group (NG).

Obesity at the first prenatal visit was considered a predictor variable. The outcome variables were fetal weight and hyperglycemic and hypertensive disorders. Other maternal information included education (literate or not); gestational age according to the first day of the last menstrual period, and confirmed by early ultrasonography and/or Capurro index; parity; $\mathrm{CD}$ rate; the duration of labor (in minutes); bleeding during labor; and BMI obtained according to the WHO criteria, and calculated as the ratio between the weight and the height squared. ${ }^{1}$

Hyperglycemic disorders included gestational diabetes mellitus (GDM), and type 1 and 2 diabetes mellitus (DM1 and DM2), according to the Brazilian Diabetes Society. ${ }^{16}$

Hypertensive disorders included chronic hypertension, mild and severe preeclampsia, and pre-existing hypertension plus superimposed gestational hypertension, according to the Report of the National High Blood Pressure Education Program Working Group on High Blood Pressure in Pregnancy. ${ }^{17}$

Neonatal variables included fetal breech presentation diagnosed by delayed ultrasonography or during delivery; birth weight in grams; fetal macrosomia (fetal weight $\geq 4,000 \mathrm{~g}$ ); ${ }^{18}$ large for gestational age (LGA) newborns; fetal birth trauma; requiring admission to the neonatal intensive care unit (NICU); stillbirth and early neonatal mortality rates; malformations identified by ultrasound examination during pregnancy and confirmed in the postnatal period; and $\mathrm{pH}$ and base excess in the umbilical cord. Blood samples to perform the blood gas analysis were obtained from the umbilical cord immediately after birth, and were analyzed within 30 minutes using AVL OMNI Modular System equipment (Roche Diagnostics, Graz, Austria). The $\mathrm{pH}$ rates $\geq 7.10$ and $<7.3$ were considered normal, and $\mathrm{pH}$ rates $<7.10$ were associated with acidotic fetuses. ${ }^{19}$ The Apgar scores at 1 minute and 5 minutes ${ }^{20,21}$ were assessed during the first attendance in the delivery room.
The research project was approved by the Research Ethics Committee of our institution under number 142/2010.

\section{Statistical Analysis}

The demographic characteristics of the pregnant women (obese and normal) were analyzed using descriptive statistics followed by two-sided independent Student's $t$ tests for the continuous variables, and the chi-squared $\left(x^{2}\right)$ test or Fisher's exact test for the categorical variables. The relative risk was estimated as the ratio between the probability of developing an adverse outcome (that is, hyperglycemic or hypertensive disorders, macrosomia, stillbirth) in the obese group and the probability of the event occurring in the nonobese group. The data were presented as mean and standard deviation, unless otherwise indicated. We performed a multiple linear regression to investigate the effects of obesity in the newborns' body weight, adjusted by maternal age, hyperglycemic disorders and hypertensive disorders. All analyses were performed using the $R$ ( $R$ Foundation for Statistical Computing, Vienna, Austria) for Windows software, version 3.1.0. A value of $p<0.05$ was considered statistically significant.

\section{Results}

Out of the 15,495 deliveries performed at the Department of Gynecology and Obstetrics from March 1998 to June 2010, 10,111 did not have data in the medical charts about weight or height in early pregnancy, and they were excluded. Thus, 5,384 medical charts were selected. According to the BMI in early pregnancy, 295 (5.5\%) pregnant women were categorized as underweight; 3,161 (58.7\%) as normal weight; 1,197 (22.3\%) as overweight; 662 (12.3\%) as having grade 1 obesity; and 69 (1.3\%) as having grades 2 and 3 obesity.

All pregnant women with BMIs $\geq 30 \mathrm{~kg} / \mathrm{m}^{2}(n=731$; $18.8 \%$ ) and their respective newborns were included in the OG. All pregnant women with BMIs between $18.5 \mathrm{~kg} / \mathrm{m}^{2}$ and $24.9 \mathrm{~kg} / \mathrm{m}^{2}(n=3,161 ; 81.2 \%)$ and their respective newborns were included in the NG. Thus, 3,892 pregnant women were included in this study (-Table 1, - Fig. 1).

The women were older in the OG than in the NG $(28.8 \pm 6.9$ versus $24.3 \pm 8.6 ; p<0.01$ ), and there were 6.7 times more pregnant women older than 35 years of age in the OG than in the NG (35.6\% versus 5.3\%; $p<0.01$ ) ( - Table 1 ).

Hyperglycemic disorders (14.5\% versus $2.5 \%$; $p<0.01$ ) and hypertensive disorders (33.5\% versus $6.2 \%, p<0.01$ ) were more incident in the OG than in the NG. The incidence of $C D$ in the OG was 2.5 higher than in the NG (51.2\% versus $29.4 \% ; p<0.01)$. The variables education, duration of labor, and hemorrhage during labor and delivery were similar in both groups ( - Table $\mathbf{1}$ ).

Regarding the neonatal variables in both groups ( - Table 2 ), the highest rate of fetal acidosis ( 6.6 versus 3.3\%; $p<0.01$ ) and macrosomic neonates (22.7\% versus $9.2 \% ; p<0.01$ ) occurred in the OG (-Table 2). The multiple linear regression analysis shows newborn weight was on average $295.3 \mathrm{~g}$ higher in the obese group, adjusted by maternal age, hyperglycemic and hypertensive disorders. Even though the relationship was 
Table 1 Distribution of maternal and obstetric variables in the sample $(n=3,892)$ from our institution, $1998-2010$

\begin{tabular}{|c|c|c|c|c|}
\hline Maternal and obstetric variables & $\begin{array}{l}\text { Obese Group } \\
(n=731)\end{array}$ & $\begin{array}{l}\text { Normal Group } \\
(n=3,161)\end{array}$ & $p$ & $\begin{array}{l}\text { OR } \\
(95 \% \mathrm{Cl})\end{array}$ \\
\hline Age (mean \pm SD) & $28.8 \pm 6.9$ & $24.3 \pm 8.6$ & $<0.01^{d}$ & - \\
\hline Age $\geq 35^{a}$ & $260(35.6 \%)$ & $169(5.3 \%)$ & $<0.01^{\mathrm{b}}$ & $9.8(7.8-12.2)$ \\
\hline \multicolumn{5}{|l|}{ Education $^{a}$} \\
\hline Illiterate $^{\mathrm{a}}$ & $9(1.2 \%)$ & $27(0.9 \%)$ & $\mathrm{NS}^{\mathrm{c}}$ & $1.44(0.68-3.05)$ \\
\hline Literate $^{a}$ & $714(97.7 \%)$ & $3,076(97.3 \%)$ & $N S^{b}$ & $1.00(0.99-1.01)$ \\
\hline Parity (mean) & $1.8 \pm 0.5$ & $1.2 \pm 0.4$ & $N S^{d}$ & \\
\hline Hyperglycemic disorders $^{a}$ & $106(14.5 \%)$ & $80(2.5 \%)$ & $<0.01^{\mathrm{b}}$ & $6.5(4.8-8.9)$ \\
\hline Hypertensive disorders $^{a}$ & $245(33.5 \%)$ & $196(6.2 \%)$ & $<0.01^{\mathrm{b}}$ & $7.6(6.1-9.5)$ \\
\hline Cesarean delivery $^{\mathrm{a}}$ & $374(51.2 \%)$ & $929(29.4 \%)$ & $<0.01^{\mathrm{b}}$ & $2.5(2.1-3.0)$ \\
\hline \multicolumn{5}{|l|}{ Duration of labor $^{a}$} \\
\hline$\leq 360$ minutes $^{\mathrm{a}}$ & $79(10.8 \%)$ & $390(12.3 \%)$ & $N S^{b}$ & $0.87(0.69-1.10)$ \\
\hline$>360$ minutes $^{\mathrm{a}}$ & $367(50.2 \%)$ & $2,057(65.1 \%)$ & $N S^{b}$ & $0.77(0.71-0.83)$ \\
\hline Bleeding during labor ${ }^{a}$ & $6(0.8 \%)$ & $22(0.7 \%)$ & $\mathrm{NS}^{\mathrm{C}}$ & $1.14(0.56-2.32)$ \\
\hline
\end{tabular}

Abbreviations: $\mathrm{Cl}$, confidence interval;; $\mathrm{n}$, sample size; NS, not statistically significant; OR, odds ratio; SD, standard deviation.

Notes: Obese group: composed of pregnant women with BMls $\geq 30 \mathrm{~kg} / \mathrm{m}^{2}$ ); normal group: composed of pregnant women with BMls between $18.5 \mathrm{~kg} / \mathrm{m}^{2}$ and $24.9 \mathrm{~kg} / \mathrm{m}^{2}$.

Hyperglycemic disorders: gestational diabetes mellitus, and types 1 and 2 diabetes mellitus; hypertensive disorders: chronic hypertension, mild and severe preeclampsia, and pre-existing hypertension plus superimposed gestational hypertension.

${ }^{a}$ Results expressed in absolute number and percentage;

${ }^{\mathrm{b}}$ chi-squared test;

'Fisher's exact test;

'two-sided independent Student's $t$ test.

statistically different between the groups $(p<0.01)$, only $1.5 \%$ of the variability in newborn weight can be explained by the model. The neonatal variables defined as base excess, gestational age, Apgar score, breech presentation, stillbirth, NICU, early neonatal mortality, birth defects, and fetal birth trauma were not different between the two study groups.

\section{Discussion}

Our institution is responsible for $\sim 50 \%$ of births in the Public Health System for the municipality and surrounding municipalities; therefore, it provides a large population sample. This study strengthens the evidence that demonstrates the

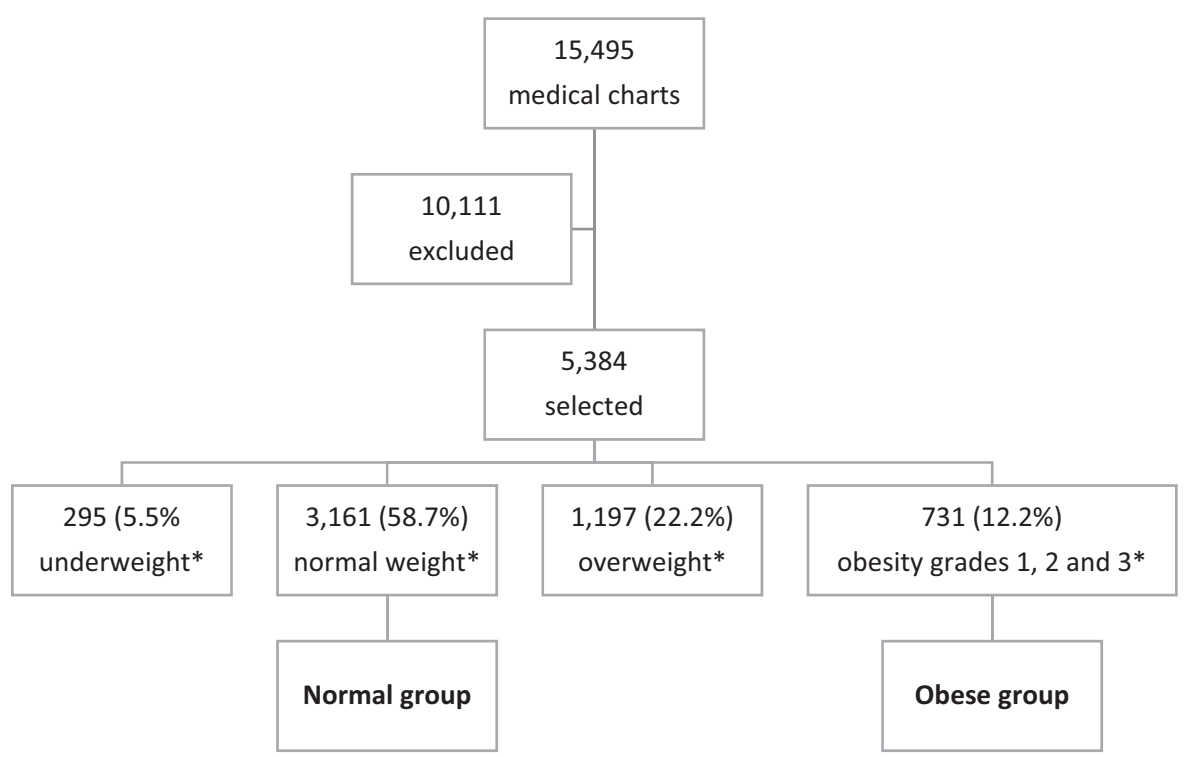

Fig. 1 The flow of the selected population through the study. Notes: ${ }^{*}$ Underweight: $\mathrm{BMI}<18.5 \mathrm{~kg} / \mathrm{m}^{2}$; normal weight: BMl between $18.5 \mathrm{~kg} / \mathrm{m}^{2}$ and $24.9 \mathrm{~kg} / \mathrm{m}^{2}$; overweight: BMl between $25 \mathrm{~kg} / \mathrm{m}^{2}$ and $29.9 \mathrm{~kg} / \mathrm{m}^{2}$; obesity grades 1,2 , and $3: \mathrm{BMl} \geq 30 \mathrm{~kg} / \mathrm{m}^{2}$. 
Table 2 Distribution of neonatal variables in the sample $(n=3,892)$ from our institution, 1998-2010

\begin{tabular}{|c|c|c|c|c|}
\hline Neonatal variables & $\begin{array}{l}\text { Obese Group } \\
n=731\end{array}$ & $\begin{array}{l}\text { Normal Group } \\
\mathrm{n}=3,161\end{array}$ & $p$ & $\begin{array}{l}\text { OR } \\
(95 \% \mathrm{Cl})\end{array}$ \\
\hline \multicolumn{5}{|l|}{ Apgar score } \\
\hline 1 minute [median IQR] & [8 7-9] & [8 7-9] & $N S^{\mathrm{d}}$ & \\
\hline 5 minute [median IQR] & [9 9-9] & [9 9-10] & $\mathrm{NS}^{\mathrm{d}}$ & \\
\hline Umbilical cord pH & $7.23 \pm 0.10$ & $7.24 \pm 0.42$ & $\mathrm{NS}^{9}$ & \\
\hline$\leq 7.1^{\mathrm{a}}$ & $48(6.6 \%)$ & $105(3.3 \%)$ & $<0.01^{\mathrm{e}}$ & $2.1(1.4-2.9)$ \\
\hline Base excess & $-6.53 \pm 3.85$ & $-6.23 \pm 3.66$ & $\mathrm{NS}^{\mathrm{g}}$ & \\
\hline Birth weight $(\mathrm{kg})$ & $3,206.5 \pm 708.8$ & $2,989.5 \pm 578.4$ & $<0.01^{9}$ & \\
\hline GA (weeks) (mean \pm SD) ${ }^{\mathrm{b}}$ & $38.4 \pm 2.9$ & $38.2 \pm 3.4$ & $\mathrm{NS}^{\mathrm{g}}$ & \\
\hline$<30(\%)$ & 0.8 & 1.2 & $N S^{f}$ & $0.68(0.29-1.60)$ \\
\hline 30 to $34(\%)$ & 4.5 & 5.4 & $\mathrm{NS}^{\mathrm{e}}$ & $0.83(0.58-1.20)$ \\
\hline 35 to 36 (\%) & 6.7 & 8.2 & $\mathrm{NS}^{\mathrm{e}}$ & $0.84(0.64-1.09)$ \\
\hline$\geq 37(\%)$ & 88.0 & 85.2 & $\mathrm{NS}^{\mathrm{e}}$ & $1.03(0.99-1.06)$ \\
\hline Breech presentation $^{a}$ & $40(5.5 \%)$ & $150(4.8 \%)$ & $\mathrm{NS}^{\mathrm{e}}$ & $1.15(0.82-1.61)$ \\
\hline Stillbirth $^{\mathrm{a}}$ & $11(1.5 \%)$ & $54(1.7 \%)$ & $\mathrm{NS}^{\mathrm{e}}$ & $0.88(0.46-1.67)$ \\
\hline Need for treatment in $\mathrm{NICU}^{\mathrm{a}}$ & $125(17.1 \%)$ & 503 (15.9\%) & $\mathrm{NS}^{\mathrm{e}}$ & $1.07(0.89-1.28)$ \\
\hline Early neonatal mortality ${ }^{\mathrm{a}}$ & $11(1.5 \%)$ & $58(1.8 \%)$ & $\mathrm{NS}^{\mathrm{e}}$ & $0.82(0.43-1.55)$ \\
\hline Fetal macrosomiac & $166(22.7 \%)$ & $292(9.2 \%)$ & $<0.01^{\mathrm{e}}$ & $\begin{array}{l}2.9(2.3-3.6) \\
1.82(1.44-2.32)^{\mathrm{h}}\end{array}$ \\
\hline Birth defects ${ }^{\mathrm{a}}$ & $4(0.6 \%)$ & $44(1.4 \%)$ & $N S^{f}$ & $0.39(0.14-1.09)$ \\
\hline Fetal birth trauma ${ }^{a}$ & $11(1.5 \%)$ & $38(1.2 \%)$ & $\mathrm{NS}^{\mathrm{e}}$ & $1.25(0.64-2.44)$ \\
\hline
\end{tabular}

Abbreviations: $\mathrm{Cl}$, confidence interval; GA, gestational age; IQR, interquartile range; NICU, Neonatal Intensive Care Unit; NS, not statistically significant; OR, odds ratio; SD, standard deviation.

Notes: Early neonatal mortality: less than 7 days;

a results expressed in absolute numbers and percentages;

${ }^{b}$ results expressed as mean \pm standard deviation;

${ }^{c}$ Fetal macrosomia, fetal weight $\geq 4,000 \mathrm{~g}$;

${ }^{\mathrm{d}}$ Mann Whitney Wilcoxon test;

e chi-squared test;

fFisher's exact test;

'two-sided independent Student's $t$ test;

hadjusted by hyperglycemic disorder.

direct association of obesity assessed by BMI with disorders during pregnancy, as well as a greater number of obstetric interventions. The data show that women older than 35 years of age were 2.5 times more likely to be obese than younger women. This observation is consistent with the studies by Pleis et $\mathrm{al}^{22}$ and Gross et $\mathrm{al}^{23}{ }^{23}$ who also reported that older pregnant women among obese pregnant women had higher parity compared with the control group. On the other hand, Stepan et $\mathrm{al}^{13}$ observed no significant difference between maternal age and gestational age in the comparison between groups with and without obesity. Studies have reported a higher risk of complications in women who start their pregnancies with a BMI above normal. ${ }^{7,23,24}$ Furthermore, obesity was related to an increased risk of preeclampsia and GDM, CD, hemorrhage, puerperal infections, birth defects, fetal death, fetal macrosomia, and maternal death during pregnancy and childbirth. ${ }^{8,10,13}$
Torloni et $\mathrm{al}^{25}$ observed that GDM was present in $24.5 \%$ of the cases of morbid obesity, and in $14.2 \%$ of pregnant women with BMI $\geq 35 \mathrm{~kg} / \mathrm{m}^{2} .{ }^{25}$ Our data show that obese women have a 6 times greater risk of developing hyperglycemic disorders ( $14.4 \%$ versus $2.5 \%$ ), and such results are consistent with those of other authors. ${ }^{9,23,26}$

We found that obesity in early pregnancy was associated with an increased risk of hypertensive disorders (33.5\% versus $6.2 \%$ ). These data are corroborated by the literature. ${ }^{9,24,26} \mathrm{We}$ also found a higher $\mathrm{CD}$ rate in the OG (51\% versus $29.4 \%$ ). This fact can be explained by the increased number of elective and iterative CDs, and fetopelvic disproportion, which is commonly related to fetal macrosomia. In this study, the risk of $C D$ was 1.7 times higher in the OG. These results are in agreement with previously published studies. ${ }^{9,27,28}$ This rate can be explained by the maternal and fetal risks, in addition to the ethical and legal aspects regarding vaginal birth after cesarean. 
The results pertaining to the newborns showed a significant increase in acidosis ( $\mathrm{pH}$ of the umbilical cord blood $\leq 7.10$ ) in newborns from obese mothers. ${ }^{29}$ Conner et al $^{30}$ also found that an increase in BMI was associated with a statistically significant increased risk of arterial cord blood $\mathrm{pH}<7.20$ and base excess $<-8$.

Stepan et $\mathrm{al}^{13}$ observed a greater need for intubation procedures and cardiac resuscitation in infants from obese mothers. Our study did not assess the need for intubation procedures or cardiac resuscitation; however, the analysis of the variables requiring treatment at a NICU and early neonatal mortality did not differ between the groups. This suggests that adequate perinatal care might have reduced the risk of complications.

The correlation of the Apgar score with neonatal health and survival is widely established. ${ }^{12,30,31}$ This parameter was assessed in our study and showed no significant difference between the groups. In a similar study, Stepan et al ${ }^{13}$ showed low Apgar scores at minute 1 along with the improvement at minutes 5 and 10 . On the other hand, in a retrospective cohort study, Abenhaim et al $^{31}$ observed the higher risk of an Apgar score $\leq 3$ at 5 minutes among obese women compared with women with normal BMIs. ${ }^{30}$

Fetal birth weight was statistically higher in the newborns of obese mothers $(3,200 \mathrm{~g} \pm 708 \mathrm{~g})$ compared with nonobese mothers $(2,989 \mathrm{~g} \pm 578 \mathrm{~g})$. Similarly, Bautista-Castaño et $\mathrm{al}^{32}$ reported that newborn weight was directly related to maternal baseline BMI. In relation to intrauterine growth restriction, our data indicate that fetal growth restriction was not influenced by BMI; however, Perlow et al $^{33}$ suggested an increased risk in massive obesity.

The current study did not identify a relationship between preterm deliveries and obesity. The reports about preterm delivery and obesity have been contradictory. Kumari et al $^{34}$ observed a decreased risk of preterm deliveries in obese women with BMIs $>40 \mathrm{~kg} / \mathrm{m}^{2}$ compared with women with normal BMIs ( 0.5 versus 5.3\%; $p<0.01$ ), which is contrary to the observations of Baeten et al. ${ }^{35}$

Although many studies have demonstrated that maternal obesity is an independent risk of occurrence of fetal neural tube defects, cardiac malformations, and orofacial clefts, ${ }^{35-38}$ our study did not find this.

A potential limitation of our study is its retrospective design. Additionally, this study did not assess the effect of gestational weight gain among the obese and control groups. It is known that women who gain weight excessively or inadequately during pregnancy are at increased risks of poor maternal and child health outcomes. ${ }^{39-42}$

In summary, our study shows that the obese women were older than the controls, and that obesity in early pregnancy increased the risk of hyperglycemic disorders, hypertensive disorders, cesarean delivery, fetal macrosomia, and fetal acidosis.

\section{References}

1 World Health Organization [Internet]. Global Health Observatory (GHO). Obesity: situation and trends. 2016 [cited 2016 Sep 10]. Available from: http://www.who.int/gho/ncd/risk_factors/obesity_text/en
2 World Health Organization [Internet]. Global Health Observatory (GHO) data. Overweight and obesity. 2016 [cited 2016 Sep 10]. Available from: http://www.who.int/gho/ncd/risk_factors/overweight/en

3 Nucci LB, Schmidt MI, Duncan BB, Fuchs SC, Fleck ET, Santos Britto MM. Nutritional status of pregnant women: prevalence and associated pregnancy outcomes. Rev Saude Publica 2001; 35(06):502-507

4 Brasil. Ministério da Saúde. Secretaria de Vigilância em Saúde [Internet]. Vigitel Brasil 2013: vigilância de fatores de risco e proteção para doenças crônicas por inquérito telefônico. Brasília (DF): Ministério da Saúde; 2014 [cited 2016 Set 10]. Available from: https://biavati.files.wordpress.com/2014/05/vigitel-2013.pdf

5 Tennant PW, Rankin J, Bell R. Maternal body mass index and the risk of fetal and infant death: a cohort study from the North of England. Hum Reprod 2011;26(06):1501-1511

6 Aune D, Saugstad OD, Henriksen T, Tonstad S. Maternal body mass index and the risk of fetal death, stillbirth, and infant death: a systematic review and meta-analysis.JAMA 2014;311(15):1536-1546

7 Nohr EA, Vaeth M, Baker JL, Sørensen TIa, Olsen J, Rasmussen KM. Combined associations of prepregnancy body mass index and gestational weight gain with the outcome of pregnancy. Am J Clin Nutr 2008;87(06):1750-1759

8 Sebire NJ, Jolly M, Harris JP, et al. Maternal obesity and pregnancy outcome: a study of 287,213 pregnancies in London. Int J Obes Relat Metab Disord 2001;25(08):1175-1182

9 Chu SY, Kim SY, Schmid CH, et al. Maternal obesity and risk of cesarean delivery: a meta-analysis. Obes Rev 2007;8(05):385-394

10 Cedergren MI. Maternal morbid obesity and the risk of adverse pregnancy outcome. Obstet Gynecol 2004;103(02):219-224

11 Anderson JL, Waller DK, Canfield MA, Shaw GM, Watkins ML, Werler MM. Maternal obesity, gestational diabetes, and central nervous system birth defects. Epidemiology 2005;16(01):87-92

12 Ray JG, Wyatt PR, Vermeulen MJ, Meier C, Cole DE. Greater maternal weight and the ongoing risk of neural tube defects after folic acid flour fortification. Obstet Gynecol 2005;105(02):261-265

13 Stepan H, Scheithauer S, Dornhöfer N, Krämer T, Faber R. Obesity as an obstetric risk factor: does it matter in a perinatal center? Obesity (Silver Spring) 2006;14(05):770-773

14 Rasmussen SA, Chu SY, Kim SY, Schmid CH, Lau J. Maternal obesity and risk of neural tube defects: a metaanalysis. Am J Obstet Gynecol 2008;198(06):611-619

15 Johansson S, Villamor E, Altman M, Bonamy AKE, Granath F, Cnattingius S. Maternal overweight and obesity in early pregnancy and risk of infant mortality: a population based cohort study in Sweden. BMJ 2014;349:g6572

16 Institute of Medicine. National Research Council. Committee to Reexamine IOM Pregnancy Weight Guidelines. Food and Nutrition Board and Board on Children, Youth and Families. Weight gain during pregnancy: reexamining the guidelines. Washington (DC): National Academies Press; 2009

17 Sociedade Brasileira de Diabetes [Internet]. Diretrizes Sociedade Brasileira de Diabetes 2015-2016. 2016 [cited 2016 Set 26]. Available from: http://bibliofarma.com/diretrizes-sbd-2015-2016/

18 Report of the National High Blood Pressure Education Program Working Group on High Blood Pressure in Pregnancy. Am J Obstet Gynecol 2000;183(01):S1-S22

19 Battaglia FC, Lubchenco LO. A practical classification of newborn infants by weight and gestational age.J Pediatr 1967;71(02):159-163

20 ACOG Committee on Obstetric Practice. ACOG Committee Opinion No. 348, November 2006: Umbilical cord blood gas and acidbase analysis. Obstet Gynecol 2006;108(05):1319-1322

21 Casey BM, McIntire DD, Leveno KJ. The continuing value of the Apgar score for the assessment of newborn infants. N Engl J Med 2001;344(07):467-471

22 Pleis JR, Lethbridge-Cejku M. Summary health statistics for U.S. adults: National Health Interview Survey, 2006. Vital Health Stat 10 2007;(235):1-153 
23 Gross T, Sokol RJ, King KC. Obesity in pregnancy: risks and outcome. Obstet Gynecol 1980;56(04):446-450

24 Bodnar LM, Catov JM, Klebanoff MA, Ness RB, Roberts JM. Prepregnancy body mass index and the occurrence of severe hypertensive disorders of pregnancy. Epidemiology 2007;18(02):234-239

25 Torloni MR, Betrán AP, Horta BL, et al. Prepregnancy BMI and the risk of gestational diabetes: a systematic review of the literature with meta-analysis. Obes Rev 2009;10(02):194-203

26 Baron CM, Girling LG, Mathieson AL, et al. Obstetrical and neonatal outcomes in obese parturients. J Matern Fetal Neonatal Med 2010;23(08):906-913

27 Chandrasekaran S, Levine LD, Durnwald CP, Elovitz MA, Srinivas SK. Excessive weight gain and hypertensive disorders of pregnancy in the obese patient. J Matern Fetal Neonatal Med 2015; 28(08):964-968

28 Rode L, Nilas L, Wøjdemann K, Tabor A. Obesity-related complications in Danish single cephalic term pregnancies. Obstet Gynecol 2005; 105(03):537-542

29 Gunatilake RP, Smrtka MP, Harris B, et al. Predictors of failed trial of labor among women with an extremely obese body mass index. Am J Obstet Gynecol 2013;209(06):562.e1-562.e5

30 Conner SN, Tuuli MG, Longman RE, Odibo AO, Macones GA, Cahill AG. Impact of obesity on incision-to-delivery interval and neonatal outcomes at cesarean delivery. Am J Obstet Gynecol 2013; 209(04):386.e1-386.e6

31 Abenhaim HA, Kinch RA, Morin L, Benjamin A, Usher R. Effect of prepregnancy body mass index categories on obstetrical and neonatal outcomes. Arch Gynecol Obstet 2007;275(01):39-43

32 Bautista-Castaño I, Henriquez-Sanchez P, Alemán-Perez N, et al. Maternal obesity in early pregnancy and risk of adverse outcomes. PLoS One 2013;8(11):e80410
33 Perlow JH, Morgan MA, Montgomery D, Towers CV, Porto M. Perinatal outcome in pregnancy complicated by massive obesity. Am J Obstet Gynecol 1992;167(4 Pt 1):958-962

34 Kumari AS. Pregnancy outcome in women with morbid obesity. Int J Gynaecol Obstet 2001;73(02):101-107

35 Baeten JM, Bukusi EA, Lambe M. Pregnancy complications and outcomes among overweight and obese nulliparous women. Am J Public Health 2001;91(03):436-440

36 Shaw GM, Velie EM, Schaffer D. Risk of neural tube defectaffected pregnancies among obese women. JAMA 1996; 275(14):1093-1096

37 Watkins And ML, Botto LD. Maternal prepregnancy weight and congenital heart defects in the offspring. Epidemiology $2001 ; 11$ (04):439-446

38 Watkins ML, Rasmussen SA, Honein MA, Botto LD, Moore CA. Maternal obesity and risk for birth defects. Pediatrics 2003;111 (5 Pt 2):1152-1158

39 Stothard KJ, Tennant PW, Bell R, Rankin J. Maternal overweight and obesity and the risk of congenital anomalies: a systematic review and meta-analysis. JAMA 2009;301(06):636-650

40 Paulino DS, Surita FG, Peres GB, do Nascimento SL, Morais SS. Association between parity, pre-pregnancy body mass index and gestational weight gain. J Matern Fetal Neonatal Med 2016; 29(06):880-884

41 Godoy AC, Nascimento SL, Surita FG. A systematic review and meta-analysis of gestational weight gain recommendations and related outcomes in Brazil. Clinics (Sao Paulo) 2015;70(11): 758-764

42 Guelinckx I, Devlieger R, Beckers K, Vansant G. Maternal obesity: pregnancy complications, gestational weight gain and nutrition. Obes Rev 2008;9(02):140-150 